\title{
Technology Use and Frailty for Community Dwelling Older Adults: A Scoping Review
}

\author{
Chava Pollak ${ }^{1 *} \&$ Sharon Wexler ${ }^{1}$ \\ ${ }^{1}$ Pace University, New York, NY, USA \\ *Corresponding Author - Chava Pollak, Pace University, New York, USA. Email: cs68128p@ pace.edu \\ DOI: https://dx.doi.org/10.47988/janany.44473381.1.1
}

\begin{abstract}
Background: Frailty is a common geriatric syndrome defined as a state of increased vulnerability to acute stressors related to a decline in reserve. There is abundant literature on frailty interventions, however, the literature on technology as an intervention for frailty is scarce.
\end{abstract}

Objectives: The purpose of this scoping review is to identify and summarize existing evidence on technology use as an intervention for frail older adults and to identify research gaps in the evidence base in order to inform future research.

Methodology: This review utilized the Preferred Reporting Items for Systematic Reviews and Meta-Analyses (PRISMA) guidelines and a rigorous scoping review method to search the literature. A comprehensive search of computerized databases was conducted in July 2018 in the following databases published from 2013 to 2018 : CINAHL, PubMed, and Academic Search Complete.

Results: The database searches yielded a total of 183 articles. Forty-four duplicates were removed. There were 114 results excluded based on title and abstract ineligibility. Thirty-two relevant articles were retrieved for fulltext examination. Eighteen of the articles were excluded based on the inclusion or exclusion criteria. References of 14 included articles were hand-searched for relevant works to ensure completeness of the search. Four pertinent additional articles were identified. The final analysis included 18 articles.

Discussion: Current research on technology use for frail older adults focuses on assessment and diagnosis. Methodological weaknesses limit generalizability and the validity of its findings. Few studies utilize frailty as an outcome measure, limiting available research directly related to frailty.

Conclusion: More research is needed on the potential for technological tools as interventions for frailty in older adults living at home, specifically, to prevent pre-frailty and frailty.

Keywords: frailty, frail elderly, aged, independent living, technology

Funding: The authors did not receive any funding from the public, commercial, or not-for-profit sectors.

Conflict of Interest: The authors declare no actual or potential conflict of interest. 


\section{Technology Use and Frailty for Community Dwelling Older Adults: A Scoping Review}

Frailty is a common geriatric syndrome, defined as a clinically recognizable state of increased vulnerability to adverse outcomes related to a decline in reserve across multiple systems, diminishing the ability to respond to acute, even minor, stressors such as surgery, loss of a spouse, minor infection, or change in medication regimen (Clegg et al., 2013). This decline in reserve places the individual at greater risk for poor health outcomes, including falls, disability, hospitalization, institutionalization, and mortality (Buckinx et al., 2015; Chang \& Lin, 2015; Fried et al., 2001; Kane et al., 2012; Xue, 2011). Pre-frailty is a term used to describe a state of elevated risk for frailty where significant functional decline is not yet evident (Fried et al., 2001). This early stage represents a crucial intervention point when preventative measures would be most effective to implement. Frailty is a dynamic, reversible process with the potential for improvement, rather than an inevitable spiral of decline (Conroy \& Elliot, 2016). Individuals transition between frailty states with potential for recovery from frail, pre-frail to robust status (Siriwardhana et al., 2018). This review focuses on community-dwelling older adults, defined as older adults living independently in the community, because this population is more commonly pre-frail, and will therefore potentially benefit most from early identification and intervention (Feng et al., 2017; Xue, 2011).

\section{Background}

Currently, there is no clear consensus regarding the definition of frailty, creating challenges in the identification and evaluation of frailty in older adults. However, it is commonly agreed that frailty is a clinically recognizable state of increased vulnerability to adverse outcomes related to a decline in physiologic reserve (Rockwood \& Mitnitski, 2011; Siriwardhana et al., 2018). This is the definition of frailty that will be used for the purposes of this review.

The two most commonly used definitions of frailty are the Fried phenotype and the Frailty Index (FI) (Clegg et al., 2013; Kojima et al., 2018; Siriwardhana et al., 2018). The frailty phenotype defines frailty as a condition meeting three out of five phenotypic criteria including weight loss, exhaustion, low physical activity, slowness and weakness, reflecting underlying loss of physiologic reserve (Fried et al., 2001). The phenotype further identifies three stages of frailty, ranging from robust, pre-frail, and frail (Fried et al., 2001). The pre-frail stage is a transitional state, where one or two criteria are present and suggests a higher risk of progression to frailty (Fried et al., 2001). Critique of this definition is that it is limited to physiologic and functional domains and does not reflect the multi-dimensional nature of the frailty syndrome. With complex, multifactorial geriatric syndromes such as frailty, it is crucial to consider relevant domains outside of a discrete biological framework (Inouye et al., 2007).

The FI measures frailty by the number of accumulated deficits across multiple domains, including physical and cognitive impairment, comorbidities, disability, psychosocial risk factors, and geriatric syndromes such as falls, delirium, and incontinence (Rockwood \& Mitnitski, 2011). The increased number of deficits are predictive of adverse health outcomes, including mortality (Kojima et al., 2018; Mitnitski et al., 2017). People, on average accumulate deficits as they age, however, the nature of the deficit and the rate at which they accumulate varies from person to person, reflecting the heterogeneity and complexity of the frailty phenomenon (Rockwood \& Mitnitski, 2011). The use of the FI requires a comprehensive geriatric assessment (Rockwood \& Mitnitski, 2011), thus limiting its practicality in everyday clinical practice due to potential time constraints.

In the absence of a gold standard defining frailty, prevalence rates vary widely from $4-59 \%$ across multiple frailty measures (Buckinx et al., 2015; Collard et al., 2012), presenting a potentially considerable population at risk. Trends suggest frailty increases with age, affects more women than men, is greater among African Americans than Caucasians, and is more prevalent among people with lower education, lower income, and higher rates of comorbidities (Buckinx et al., 2015; Collard et al., 2012; Feng et al., 2017; Xue, 2011). Additionally, nursing home residents are more likely to be frail than community-dwelling people; however, institutionalization could be a consequence of frailty itself (Buckinx et al., 2015). Frailty is a public health concern as it identifies individuals with a greater need for healthcare intervention and at high risk for dependency (Buckinx et al., 2015). Frailty is associated with disability in activities of daily living (ADLs), which are crucial for the maintenance of independent living (Kojima, 2017; Provencher et al., 2017). Since many older adults prefer to live at home, this represents a crucial intervention area to promote quality of life in this population.

Interventions to prevent and ameliorate frailty can improve older adults' lives, improve health, reduce adverse outcomes, and allow for maintenance of an independent lifestyle. A review of available literature reveals plentiful research on frailty interventions. Several systematic reviews and meta-analyses examined existing evidence for multiple frailty interventions (Apostolo et al., 2018; Chang \& Lin, 2015; De Labra et al., 2015; De Vries et al., 2012; Puts et al., 2017; Silva et al., 2018; Theou et al., 2011). Studies indicated physical exercise effectively improved mobility and functional status in frail older adults (De Labra et al., 2015; De Vries et al., 2012). Nutritional interventions, such as protein supplementation, were also useful for targeting specific frailty markers, including nutritional deficiencies and weight loss (Apostolo et al., 2018). Multifactorial, multidisciplinary interventions were most effective in reducing frailty levels, specifically combined nutrition and exercise interventions (Apostolo et al., 2018; De Labra, 2015). Notably, there is little mention of technology as an intervention for frailty in the literature. Several recent studies explored the potential for technology as a tool for enhancing independence and quality of life, reducing healthcare costs by preventing and managing disability, along with frailty in the elderly (Pilotto et al., 2018). Domestic appliances that control and manage the physical environment can maintain and improve functional capacity in older adults living at home, such as sensor technology to detect fall risk and improve gait and mobility (Pilotto et al., 2018). Wearable technologies allow for remote evaluation and monitoring of frailty 
and fall risk during daily activities, enabling early intervention (Armstrong et al., 2017). Most older adults prefer to live at home, and new and emerging technologies can help them do so safely and independently.

\section{The Review}

\section{Aims}

The purpose of this scoping review is to identify and summarize existing evidence relevant to technology use for frail, communitydwelling older adults in order to highlight areas of opportunity for future research. Specifically, this review focuses on technologies described in the literature for identification, assessment, prevention, and treatment for community-dwelling older adults with frailty, for use primarily by the older adults themselves. The expected increase in the elderly population will impact society in terms of increasing numbers of frail older adults with substantial need for support and interventions. Technological innovations may represent novel solutions to maintain functional abilities and independence for older adults living at home.

\section{Design}

This review used the Preferred Reporting Items for Systematic Reviews and Meta-Analyses (PRISMA) guidelines (Tricco et al., 2018) and a rigorous scoping review method to search the literature (Figure 1). The scoping review method was chosen because it is ideal for an emerging and critically under-researched area to identify trends and gaps in the literature to inform future researchers (Arksey \& O'Malley, 2005). The research question that guided this review was, "What are the current practices, standard use, and recommendations for technology use for frail, community-dwelling older adults?" The following steps were used to conduct the search: 1) identify the research question, 2) identify relevant studies, 3) study selection, 4) organize the data, and 5) summarize the results.

\section{Figure 1}

\section{PRISMA Search Strategy Flow Chart}

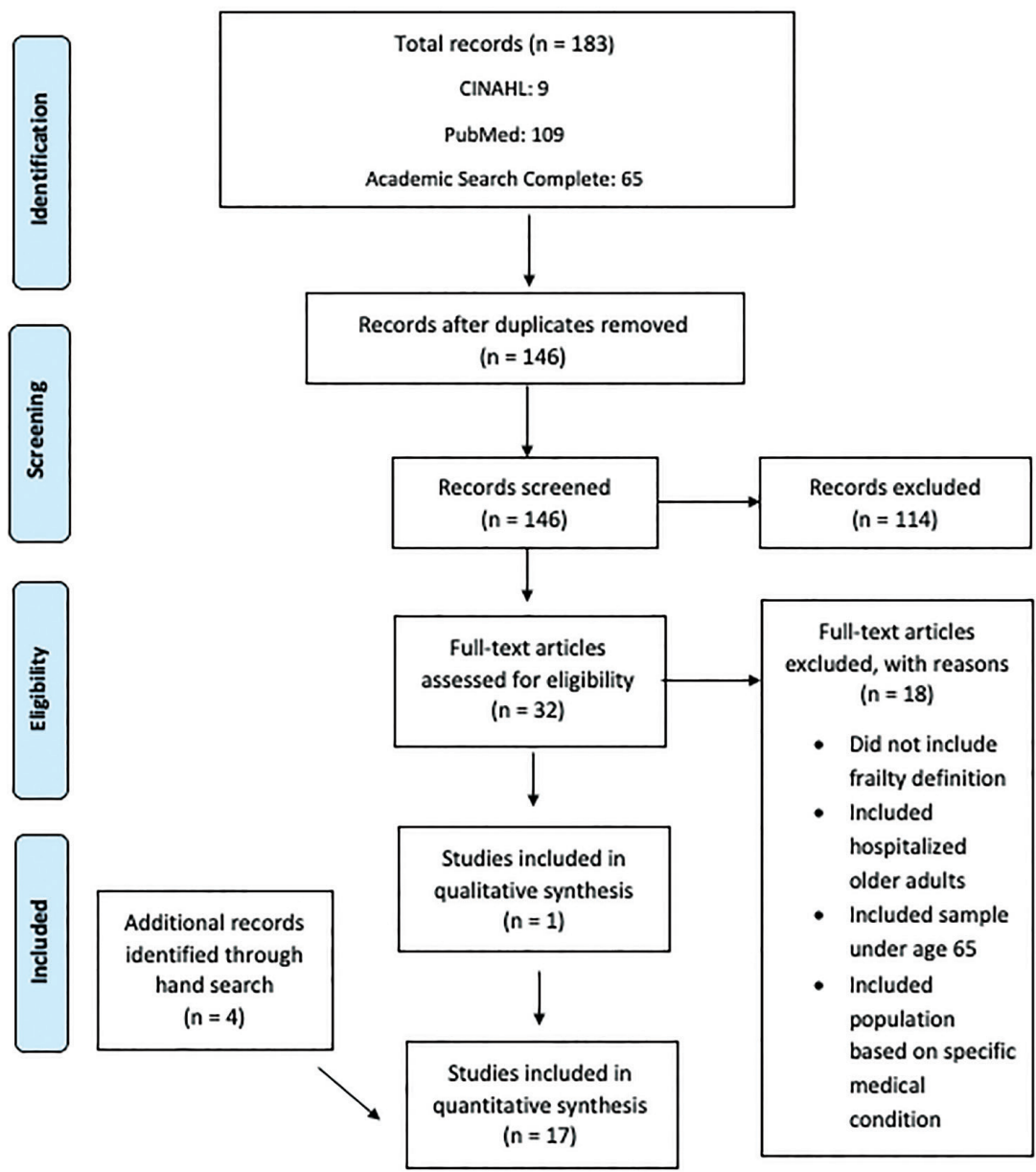

Note. From "PRISMA extension for scoping reviews (PRISMA-ScR): Checklist and explanation," by Tricco, A.C., Lillie, E., Zarin, W., O’Brien, K.K., Colquhoun, H., Levac, D.,...Straus, S.E. 2018, Annals of Internal medicine, 169, 467-473. (https://doi:10.7326/ M18-0850). 


\section{Search Methods}

After several preliminary searches to identify keywords and gain familiarity with the literature, a comprehensive search of computerized databases was conducted in July 2018 in the following databases published from 2013 to 2018: CINAHL, PubMed, and Academic Search Complete. Related subject headings, MeSH terms, and keywords were identified in consultation with research librarians to capture a comprehensive list of potential sources. MeSH terms were identified and used to search the PubMed database. Keywords and subject headings were used for CINAHL and Academic Search Complete (Table 1). Finally, keywords were identified and combined to address all components of the research question: 1) elderly, 2) frailty, 3) community-dwelling, and 4) technology. The search strategy was designed to identify studies that used technology with a population of frail older adults aged 65 and over living in the community.

\section{Table 1}

\section{Search Terms}

\begin{tabular}{|c|c|c|c|}
\hline Elderly & Frailty & $\begin{array}{l}\text { Community } \\
\text { Dwelling }\end{array}$ & Technology \\
\hline $\begin{array}{l}\text { Aged [Mesh] } \\
\text { (SH) } \\
\text { Aged, } 80 \text { and } \\
\text { over }[\mathrm{MeSH}] \\
\text { frail elderly } \\
\text { [MeSH] (SH) } \\
\text { older adults } \\
\text { (KW) }\end{array}$ & $\begin{array}{l}\text { Frailty } \\
{[\mathrm{MeSH}]} \\
\text { Frailty } \\
\text { syndrome } \\
(\mathrm{SH}) \\
\text { Frail }(\mathrm{KW}) \\
\text { prefrail } \\
(\mathrm{KW}) \\
\text { prefrailty } \\
(\mathrm{KW})\end{array}$ & $\begin{array}{l}\text { community } \\
\text { living (SH) } \\
\text { community } \\
\text { dwelling } \\
(\mathrm{KW}) \\
\text { Independent } \\
\text { Living } \\
{[\mathrm{MeSH}]} \\
\text { Residence } \\
\text { characteristics } \\
{[\mathrm{MeSH}]}\end{array}$ & $\begin{array}{l}\text { Geriatrics/ } \\
\text { instrumentation } \\
\text { [MeSH]) } \\
\text { Technology } \\
\text { [Mesh] (SH) } \\
\text { Assistive } \\
\text { technology } \\
\text { (SH) } \\
\text { Telehealth (SH) } \\
\text { Ehealth (KW) } \\
\text { Mhealth (KW) } \\
\text { Telemedicine } \\
\text { [MeSH] (SH) } \\
\text { Wearable } \\
\text { electronic } \\
\text { devices [MeSH] } \\
\text { Remote } \\
\text { monitoring } \\
\text { (KW) } \\
\text { Virtual reality } \\
\text { [MeSH] } \\
\text { Robotics } \\
\text { [MeSH] } \\
\text { Smartphone } \\
\text { [MeSH] }\end{array}$ \\
\hline
\end{tabular}

Note. $\mathrm{KW}=$ Keyword; $\mathrm{SH}=$ Subject Heading; $\mathrm{MeSH}=$ Medical Subject Heading

Articles were included if they met the following criteria: 1) focused on adults aged 65 and over living in the community; 2) peer-reviewed; 3) published in the English language; 4) featured randomized controlled trials (RCTs), cohort studies, or qualitative research; and 5) include an operationalized definition of frailty. These criteria were chosen to meet this review's focus, namely technologies used for frail older adults living at home. The search was limited to the years 2013-2018 for practicality, to identify how technology was most recently used for the study population. Articles were excluded if they: 1) focused on adults younger than 65 or children; 2) included hospitalized older adults; 3) were published in a language other than English; 4) were study protocols, conference abstracts, unpublished dissertations or commentaries; 5) were measurement tool use or development studies; or 6) selected the target population based on the presence of a specific medical condition. As the search evolved, inclusion and exclusion criteria were revised to best address the research question (Table 2).

\section{Table 2}

\section{Inclusion and Exclusion Criteria}

\begin{tabular}{|l|l|}
\hline Inclusion & Exclusion \\
\hline $\begin{array}{l}\text { Older adults over the age of } \\
\text { 65 living in the community }\end{array}$ & Adults under 65 or children \\
\hline Peer-reviewed & $\begin{array}{l}\text { Hospitalized/institutionalized } \\
\text { older adults }\end{array}$ \\
\hline English language & $\begin{array}{l}\text { Published in non-English } \\
\text { language }\end{array}$ \\
\hline $\begin{array}{l}\text { RCT, cohort studies or } \\
\text { qualitative research }\end{array}$ & $\begin{array}{l}\text { Systematic review, study } \\
\text { protocols, conference } \\
\text { abstracts, unpublished } \\
\text { dissertations or commentaries }\end{array}$ \\
\hline $\begin{array}{l}\text { Operationalized definition of } \\
\text { frailty }\end{array}$ & $\begin{array}{l}\text { Measurement tool use or } \\
\text { development studies }\end{array}$ \\
\hline & $\begin{array}{l}\text { Selected the target population } \\
\text { based on the presence of a } \\
\text { specific medical condition }\end{array}$ \\
\hline
\end{tabular}

\section{Search Outcomes}

The database searches, as described above yielded a total of 183 articles. There were 41 duplicates, which were removed. One hundred fourteen of the results were excluded based on title and abstract. Thirty-two articles relevant to this review were retrieved for full-text examination. Eighteen of the articles were excluded based on inclusion or exclusion criteria. Fourteen of the articles met all inclusion criteria. References of those articles were then hand searched for relevant works to ensure the completeness of the search, after which four additional relevant articles were identified. The final analysis included 18 articles from several different countries including Ireland $(n=2)$, Japan $(n=1)$, Spain $(\mathrm{n}=4)$, the Netherlands $(\mathrm{n}=3)$, and the United States $(\mathrm{n}=8)$ (Table 3).

\section{Results/Synthesis}

The small number of studies included in this review indicates research on technology use for community-dwelling frail older adults with confirmed frailty status is limited. Analysis of included studies is organized by their objectives, namely frailty assessment, frailty intervention, and technology use. Studies are further grouped by assessment methods such as gait parameters, performance-based measures, and upper extremity frailty. An additional subheading was included to assess studies that 
examined frailty proxy measures such as fall risk. The technology use category includes qualitative data on the use of technology in older adults.

\section{Frailty Intervention}

The impact of technology-supported, home-based exercise programs for frail older adults were evaluated (Dekker-van Weering et al., 2017; Garaedts et al., 2017). The studies were designed for the frail elderly living at home but did not measure frailty as an outcome. Instead, the studies used a frailty measure to identify frail individuals as part of inclusion criteria, however, frailty status was not measured as an outcome of the intervention. Studies used outcome measures such as gait performance, muscle strength, physical performance tests such as the Times Up and Go (TUG) test, which tangentially include aspects of frailty but fail to use a standardized frailty measure. Other outcome measures included adherence to an intervention such as an exercise program or user opinion regarding a proposed intervention. These research studies concluded that a combination of strength and balance training was most effective in addressing frailty in older adults (Dekker-van Weering et al., 2017; Geraedts et al., 2017; Ozaki et al., 2017). Internet connectivity was a common problem with home-based technologies and was noted as an important factor in study dropout rates (Geraedts et al., 2017). The long-term impact of technology-based exercise interventions was not evaluated.

\section{Frailty Assessment}

The most commonly used frailty definition in the included research was the Fried phenotype criteria (Galan-Mercant \& Cuesta-Vargas, 2013; Galan-Mercant \& Cuesta-Vargas, 2014; Galan-Mercant \& Cuesta-Vargas, 2015; Greene et al., 2014a; Greene et al., 2014b; Martinez-Ramirez et al., 2015; Mohler et al., 2016; Muchna et al., 2018; Ozaki et al., 2017; Parvaneh et al., 2017; Rahemi et al., 2018; Razjouyan et al., 2018; Rye-Hanton et al., 2017; Toosizadeh et al., 2015). Twelve articles included in this review discussed technology-based assessment, diagnosis, and classification of frailty. Four of these studies examined different aspects of frailty in subsamples of the same cohort, namely, the Arizona Frailty Cohort (Mohler et al., 2016; Muchna et al., 2018; Schwenk et al., 2015; Toosizadeh et al., 2015). The instruments used for evaluation include body-worn sensors, sensors embedded in smartphones, and pendant sensors. The research studies evaluated various frailty-related parameters to complement or replace time and resource-intensive frailty assessment in the community setting. The use of these technologies for frailty identification was suggested as a tool for early identification of frailty during daily activities that may not be detectable on clinical exam in order to identify individuals who would benefit from early intervention.

\section{Gait Parameters}

Gait parameters were often used to identify frail individuals, as slowed gait and decreased muscle strength are known markers of frailty (Fried et al., 2001). Studies that evaluated pendant sensors, body sensors, as well as smartphone sensors identified specific gait parameters associated with frailty including, decreased step count, reduced gait speed, gait and stride irregularity, and decreased overall physical activity (Martinez-Ramirez et al., 2015; Rahemi et al., 2018; Razjouyan et al., 2018; Rye-Hanton et al., 2017; Schwenk et al., 2015). Various wearable and inertial sensors were used to identify individuals with frailty and distinguish between robust, pre-frail, and frail individuals. These sensors were suggested for use for remote frailty monitoring as the sensors can be worn at home and did not require skilled monitoring (Martinez-Ramirez et al., 2015; Rahemi et al., 2018; Razjouyan et al., 2018; Rye-Hanton et al., 2017; Schwenk et al., 2015).

\section{Performance-Based Measures}

Sensor-based measures of sit-to-stand and stand-to-sit transitions and the TUG test evaluated the use of wearable technology to complement or improve the accuracy of traditional frailty assessment methods (Galan-Mercant \& Cuesta-Vargas, 2015; Greene et al., 2014a; Greene et al., 2014b) or to allow for non-expert assessment in unsupervised settings (Greene et al., 2014a; Greene et al., 2014b). Smartphone embedded sensors and chest-worn sensors were sensitive for frailty identification by capturing postural position changes during functional tasks that individuals often perform during the day, such as rising from a chair and turning around while walking (Galan-Mercant \& Cuesta-Vargas, 2013; Parvaneh et al., 2017). Postural transitions and functional tasks were restricted in frail older adults as they compensated for frailty with increasingly careful movements (Galan-Mercant \& Cuesta-Vargas, 2013; Parvaneh et al., 2017).

Various sensors were used to identify frail individuals during the performance of functional tasks during physical performance tests, including the TUG test and the sit-to-stand test (GalanMercant \& Cuesta-Vargas, 2014; Galan-Mercant \& CuestaVargas, 2015; Greene et al., 2014a; Greene et al., 2014b). These studies identified individuals with frailty via body-worn sensor data alone (Galan-Mercant \& Cuesta-Vargas, 2014; GalanMercant and Cuesta-Vargas, 2015). They also validated use of these sensors for frailty identification compared to established frailty measures such as the Fried phenotype (Greene et al., 2014a; Greene et al., 2014b). These measures were important for homebased use as they can be helpful in identifying frailty during nonmonitored activities that individuals perform in their daily lives. Additionally, the technologies can be used by non-skilled users out of the clinical environment.

\section{Upper Extremity Frailty}

A study by Toosizadeh et al. (2015) presented an innovative method of identifying frailty categories using several upper extremity assessment parameters of elbow flexion. Results showed this upper extremity task discriminated between frailty groups; slowness discriminated between pre-frail and non-frail older adults, while weakness discriminated between pre-frail and frail older adults (Toosizadeh et al., 2015). This assessment method was proposed as advantageous over the standard Fried criteria assessment as a shorter and less strenuous task that still included several frailty markers (Toosizadeh et al., 2015). This method also did not include gait assessment, making it possible for use in individuals with gait problems or where inadequate space is available (Toosizadeh et al., 2015). 


\section{Frailty Proxy Measures}

Wearable sensors were operationalized as devices that evaluated various gait performance measures as predictors of fall risk (Mohler et al., 2016; Muchna et al., 2018). While participants were screened for frailty, this information was utilized to describe the sample rather than the study outcome (Mohler et al., 2016; Muchna et al., 2018). Falls are a known adverse outcome of frailty and, along with gait abnormalities, are often used as a proxy measure for frailty in studies.

\section{Level of Technology Use}

Only one study by Peek et al. (2016) qualitatively explored the level of technology use by older adults living at home. Six major themes influenced the level of technology use in the context of aging in place: challenges in the domain of independent living, the influence of the social network, the influence of organizations, and the role of the physical environment (Peek et al., 2016). This highlighted the importance of technological solutions to consider older adults' personal, social, and physical context to optimize use.

\section{Discussion}

The aim of this scoping review was to identify and summarize existing evidence related to technology use for frail older adults living at home and to highlight research gaps in the evidence base. This review included studies that explored technologies used by older adults themselves, rather than peripheral technologies that individuals would not directly engage with, such as home monitoring systems. The purpose was to identify what technologies are currently being used for the frail older adult population and identify areas of opportunity for future research on other technologies that will maintain and increase the independence of frail older adults living at home.

Research on technology for frail older adults living at home is heavily dominated by methods for frailty assessment and identification. Only three studies in this review focused on technologies for use as an intervention for frailty in communitydwelling older adults (Dekker-van Weering, 2017; Garaedts, 2017; Ozaki et al., 2017). Furthermore, there is an added emphasis on using technologies to identify pre-frailty as a critical point for preventing and reversing frailty progression. Technologies can do this more efficiently and effectively than clinical evaluation as they can capture subtle changes in strength, functional performance, and gait. Wearable sensors and those embedded in smartphones offer tremendous potential to measure an individual's daily activity over prolonged periods in a non-invasive, inexpensive manner. Parameters that identify pre-frailty are particularly pivotal in this sense. Pre-frailty presents a decisive intervention point to prevent a spiral decline into frailty or to halt the progression of functional decline (Xue, 2011). Home-based sensors offer a possible solution for capturing subtle changes in individual behaviors that may not be evident during a routine clinical assessment and may signify muted indications of health status deterioration.

Following frailty identification, intervention is essential to prevent functional decline. However, there is a dearth of available evidence on the application of technology as an intervention for frailty in community-dwelling older adults, especially interventions measuring frailty as an outcome. Technology administered or facilitated exercise programs may enable broader access to this intervention for older adults who have difficulty leaving home due to mobility or transportation issues. Various technologies can also provide remote, automated coaching to reduce the need for skilled, real-time assistance. Social interventions can also be deployed remotely, giving access to online group activities when an in-person meeting is not possible. This highlights an area of opportunity for future research to develop and apply innovative technologies as an intervention for frailty. Additionally, many studies evaluating technology for community-dwelling frail older adults took place in a laboratory setting, not in a real home setting, where actual implementation and conditions are unclear. Additional research is needed to imagine the future implementation of these technologies for individuals in their homes. Moreover, older adults' input should be considered when developing interventions to improve acceptability and usability.

Areas for future research include studies with larger sample sizes, and samples that include older adults with cognitive impairment. Many studies with frail older adults included small sample sizes. Larger studies are needed to improve the generalizability and validity of research outcomes. Additionally, older adults with cognitive impairment are notably missing from study samples evaluating the use of technology in cohorts of frail elderly. Cognitive frailty, or the simultaneous presence of physical frailty and cognitive impairment in older adults without a diagnosis of dementia, is an important aspect of frailty (Robertson et al., 2013) and bears further evaluation in future studies. Frailty and cognitive impairment are related, but distinct concepts that frequently co-exist (Robertson et al., 2013). The inclusion of individuals with cognitive impairment in future frailty studies is certainly warranted.

The findings of this review are especially important in light of the COVID-19 pandemic, where the toll of necessary public health measures to contain the pandemic, such as physical distancing and isolation on older adults, is yet unknown and potentially catastrophic in terms of functional deterioration, increased loneliness, and mental health challenges. These challenges highlight the necessity of technological solutions to address the needs of frail older adults living at home. This review highlights the various technologies already explored for use in the home and sheds light on how these technologies can be used in the future to meet the essential needs of frail older adults in the community. This includes remote monitoring for frailty assessment and technologically administered interventions (e.g., exercise interventions) to maintain physical function while isolating in the home and social and cognitive interventions to address the holistic needs of this population.

\section{Limitations}

Inclusion criteria in terms of types of studies included in this review were narrow, and content available in abstracts, editorials, and dissertations may have broadened the findings. Additionally, limiting inclusion to English language articles potentially eliminated relevant articles written in other languages. The narrow inclusion criteria were purposeful in the sense that this review sought to identify a very particular population at risk, namely 
adults over the age of 65 living at home, and how technology was used in this population. However, this does eliminate a larger risk pool of individuals that may warrant further study in a different context. This review also sought to identify technology used in this population, particularly those that older adults interact with directly as an intervention for frailty. Articles that discussed technologies not used by the older adult, such as those used by caregivers or healthcare providers in the service of frail older adults, were excluded. These technologies were therefore not captured in this review but may be useful for future research.

Importantly, although all studies in this review include a sample of frail older adults, none measured frailty as an outcome. Instead, studies used various gait parameters and performance measures as the study outcomes. Additionally, while there is no uniform measure for frailty employed by all studies included in this review, the Fried phenotype is used more than any other frailty definition. Some studies use frailty proxy measures such as physical disability,
ADL disability, falls, or gait parameters in place of discrete frailty assessment. The variable definitions and frailty measures employed in the literature make it difficult to cumulatively and quantitatively analyze the evidence base in this area.

\section{Conclusion}

Various effective interventions for frailty are well established in the literature. The use of technology for frail older adults is heavily concentrated on the assessment and diagnosis of frailty. More research is needed on the potential for technological tools as interventions for frailty in community-dwelling elderly, specifically for detecting and preventing pre-frailty and frailty. Future studies should include adequate sample sizes to improve the validity and generalizability of results, a focus on frail older adults with cognitive impairment, and an examination of interventions using frailty as a variable to refine the applicability and practical application of the results to the frail elderly population.

Table 3

Summary of Included Literature

\begin{tabular}{|c|c|c|c|c|}
\hline $\begin{array}{l}\text { Authors, Year, } \\
\text { Country }\end{array}$ & Design & Purpose & Sample & Results \\
\hline $\begin{array}{l}\text { Dekker-van Weering } \\
\text { et al. (2017), The } \\
\text { Netherlands }\end{array}$ & $\begin{array}{l}\text { Randomized } \\
\text { controlled trial }\end{array}$ & $\begin{array}{l}\text { To investigate the use and } \\
\text { user experience of an online } \\
\text { home-based exercise program } \\
\text { and to determine whether the } \\
\text { intervention improved quality of } \\
\text { life and health status of pre-frail } \\
\text { older adults compared to a control } \\
\text { group. }\end{array}$ & $\begin{array}{l}37 \text { pre-frail } \\
\text { community dwelling } \\
\text { older adults } \\
\text { Age } 65-75 \\
16 \text { experimental } \\
21 \text { control }\end{array}$ & $\begin{array}{l}\text { A home-based exercise } \\
\text { program is easy to use and } \\
\text { has potential in improving } \\
\text { quality of life and health } \\
\text { status in pre-frail older } \\
\text { adults living at home. }\end{array}$ \\
\hline $\begin{array}{l}\text { Galan-Mercant and } \\
\text { Cuesta-Vargas (2013), } \\
\text { Spain }\end{array}$ & $\begin{array}{l}\text { Cross-sectional } \\
\text { study }\end{array}$ & $\begin{array}{l}\text { To describe the variability of the } \\
\text { accelerations, angular velocity } \\
\text { and displacement of the trunk } \\
\text { during the sit to stand and stand } \\
\text { to sit transitions in two groups of } \\
\text { frail and physically active elderly } \\
\text { persons through instrumentation } \\
\text { with the smartphone. }\end{array}$ & $\begin{array}{l}30 \text { older adults } \\
\text { Age }>65 \\
14 \text { frail } \\
16 \text { non-frail }\end{array}$ & $\begin{array}{l}\text { The inertial sensor fitted } \\
\text { in the iPhone } 4 \text { can } \\
\text { analyze kinematics of the } \\
\text { Si-St and St-Si transitions } \\
\text { in frail and robust older } \\
\text { adults to discriminate } \\
\text { between the two groups. }\end{array}$ \\
\hline $\begin{array}{l}\text { Galan-Mercant and } \\
\text { Cuesta-Vargas (2014), } \\
\text { Spain }\end{array}$ & $\begin{array}{l}\text { Cross-sectional } \\
\text { study }\end{array}$ & $\begin{array}{l}\text { To measure and describe the } \\
\text { variability of acceleration, angular } \\
\text { velocity and trunk displacement } \\
\text { in the } 10 \mathrm{~m} \text { TUG test through } \\
\text { instrumentation with the iPhone } 4 \text {. }\end{array}$ & $\begin{array}{l}30 \text { older adults } \\
\text { Age }>65 \\
14 \text { frail } \\
16 \text { non-frail }\end{array}$ & $\begin{array}{l}\text { The inertial sensor in the } \\
\text { iPhone } 4 \text { is capable of } \\
\text { studying and analyzing } \\
\text { the kinematics of the TUG } \\
\text { test in frail and non-frail } \\
\text { elderly; allows for more } \\
\text { sensitive differentiation } \\
\text { between the two groups } \\
\text { than the traditionally used } \\
\text { variable of time. }\end{array}$ \\
\hline
\end{tabular}




\begin{tabular}{|c|c|c|c|c|}
\hline $\begin{array}{l}\text { Galan-Mercant and } \\
\text { Cuesta-Vargas (2015), } \\
\text { Spain }\end{array}$ & $\begin{array}{l}\text { Cross-sectional } \\
\text { study }\end{array}$ & $\begin{array}{l}\text { To determine the series of } \\
\text { kinematic variables with } \\
\text { the greatest precision in } \\
\text { discriminating between frail } \\
\text { and non-frail elderly in the } 10 \mathrm{~m} \\
\text { TUG test using inertial sensors } \\
\text { embedded in the iPhone } 4 \\
\text { compared to the traditional time } \\
\text { variable. }\end{array}$ & $\begin{array}{l}30 \text { older adults } \\
\text { Age }>65 \\
14 \text { frail } \\
16 \text { non-frail }\end{array}$ & $\begin{array}{l}\text { Kinematic variables } \\
\text { obtained from inertial } \\
\text { sensors embedded in } \\
\text { smartphone technology } \\
\text { during the TUG test can } \\
\text { discriminate between } \\
\text { frailty status. }\end{array}$ \\
\hline $\begin{array}{l}\text { Geraedts et al. (2017), } \\
\text { The Netherlands }\end{array}$ & $\begin{array}{l}\text { Prospective } \\
\text { cohort study }\end{array}$ & $\begin{array}{l}\text { To evaluate the feasibility and user } \\
\text { opinion of a home-based exercise } \\
\text { program supported by a sensor } \\
\text { and tablet application }\end{array}$ & $\begin{array}{l}40 \text { frail, community } \\
\text { dwelling older adults } \\
\text { Age }>70 \\
\text { Ability to walk } \\
\text { 10m independently or } \\
\text { with walking aid }\end{array}$ & $\begin{array}{l}\text { A home-based exercise } \\
\text { program using novel } \\
\text { technology is feasible. } \\
\text { Regular coaching has } \\
\text { a positive influence on } \\
\text { adherence. }\end{array}$ \\
\hline $\begin{array}{l}\text { Greene, Doheny, } \\
\text { Kenny and Caufield } \\
\text { (2014), Ireland }\end{array}$ & $\begin{array}{l}\text { Observational, } \\
\text { cross-sectional } \\
\text { study }\end{array}$ & $\begin{array}{l}\text { To investigate the combination } \\
\text { of assessments of frailty and falls } \\
\text { risk in older adults. }\end{array}$ & $\begin{array}{l}130 \text { community } \\
\text { dwelling older adults } \\
\text { Age }>65 \\
\text { Ability to walk } \\
\text { without assistance }\end{array}$ & $\begin{array}{l}\text { Sensor data obtained from } \\
3 \text { physical assessments } \\
\text { resulted in improved } \\
\text { classification of falls risk } \\
\text { and frailty. }\end{array}$ \\
\hline $\begin{array}{l}\text { Greene, Doheny, } \\
\text { O'Halloran and } \\
\text { Kenny (2014), Ireland }\end{array}$ & $\begin{array}{l}\text { Observational, } \\
\text { cross-sectional } \\
\text { study }\end{array}$ & $\begin{array}{l}\text { To investigate a fast method for } \\
\text { automatic, quantitative assessment } \\
\text { of the frailty state based on a } \\
\text { simple protocol employing body } \\
\text { worn inertial sensors }\end{array}$ & $\begin{array}{l}399 \text { community } \\
\text { dwelling older adults } \\
\text { Age }>60 \\
30 \text { frail } \\
185 \text { pre-frail } \\
184 \text { non-frail } \\
115 \text { male } \\
284 \text { female }\end{array}$ & $\begin{array}{l}\text { Assessment with well- } \\
\text { known TUG mobility test } \\
\text { and inertial sensors can } \\
\text { be a fast, effective way of } \\
\text { non-expert assessment of } \\
\text { frailty }\end{array}$ \\
\hline $\begin{array}{l}\text { Martinez-Ramirez et } \\
\text { al. (2015), Spain }\end{array}$ & $\begin{array}{l}\text { Observational, } \\
\text { cross-sectional } \\
\text { study }\end{array}$ & $\begin{array}{l}\text { To investigate whether a } \\
\text { collection of parameters extracted } \\
\text { from the trunk acceleration } \\
\text { signals could provide additional } \\
\text { accurate information about frailty } \\
\text { syndrome. }\end{array}$ & $\begin{array}{l}718 \text { older adults } \\
319 \text { males } \\
399 \text { females } \\
\text { Age } 75.4+/-6.1 \\
\text { Ability to complete } \\
3 \mathrm{~m} \text { walk test at their } \\
\text { own gait velocity }\end{array}$ & $\begin{array}{l}\text { Gait parameters } \\
\text { simultaneously used } \\
\text { with gait velocity can be } \\
\text { used to more accurately } \\
\text { classify frailty status; may } \\
\text { allow for early detection } \\
\text { of pre-frailty. }\end{array}$ \\
\hline $\begin{array}{l}\text { Mohler et al. (2016), } \\
\text { USA }\end{array}$ & $\begin{array}{l}\text { Observational } \\
\text { descriptive } \\
\text { study }\end{array}$ & $\begin{array}{l}\text { To evaluate wearable sensor- } \\
\text { based measures of gait, balance, } \\
\text { and physical activity that are } \\
\text { predictive of future falls in } \\
\text { community-dwelling older adults. }\end{array}$ & $\begin{array}{l}119 \text { community } \\
\text { dwelling older adults } \\
\text { Age }>65\end{array}$ & $\begin{array}{l}\text { The association between } \\
\text { motor performance } \\
\text { and risk of falling is } \\
\text { dependent on frailty } \\
\text { status. Wearable sensor } \\
\text { is a tool for assessing fall } \\
\text { risk in the home setting. }\end{array}$ \\
\hline $\begin{array}{l}\text { Muchna et al. (2018), } \\
\text { USA }\end{array}$ & $\begin{array}{l}\text { Observational } \\
\text { descriptive } \\
\text { study }\end{array}$ & $\begin{array}{l}\text { To examine the effect of foot } \\
\text { problems on the likelihood of } \\
\text { falls, frailty syndrome, motor } \\
\text { performance and physical activity } \\
\text { in community dwelling older } \\
\text { adults. }\end{array}$ & $\begin{array}{l}117 \text { community } \\
\text { dwelling older adults } \\
41 \text { non-frail } \\
56 \text { pre-frail } \\
20 \text { frail } \\
\text { Age }>65\end{array}$ & $\begin{array}{l}\text { Foot problems are } \\
\text { associated with frailty. } \\
\text { Sensor-based gait } \\
\text { parameters can identify } \\
\text { foot problems and older } \\
\text { adults at risk for falls or } \\
\text { gait abnormalities related } \\
\text { to foot problems. }\end{array}$ \\
\hline
\end{tabular}




\begin{tabular}{|c|c|c|c|c|}
\hline $\begin{array}{l}\text { Ozaki et al. (2017), } \\
\text { Japan }\end{array}$ & Cross-over trial & $\begin{array}{l}\text { To examine the efficacy of } \\
\text { postural strategy training using } \\
\text { a balance exercise assist robot } \\
\text { as compared with conventional } \\
\text { balance training for frail older } \\
\text { adults }\end{array}$ & $\begin{array}{l}27 \text { community } \\
\text { dwelling frail or } \\
\text { prefrail older adults } \\
7 \text { men, } 20 \text { women } \\
\text { Age }>65\end{array}$ & $\begin{array}{l}\text { In frail or prefrail older } \\
\text { adults, robotic exercise } \\
\text { was more effective for } \\
\text { improving dynamic } \\
\text { balance and lower } \\
\text { extremity muscle strength } \\
\text { than conventional } \\
\text { exercise. } \\
\end{array}$ \\
\hline $\begin{array}{l}\text { Parvaneh et al. } \\
\text { (2017), USA }\end{array}$ & $\begin{array}{l}\text { Observational } \\
\text { cohort study }\end{array}$ & $\begin{array}{l}\text { To monitor and assess daily } \\
\text { postural transition differences } \\
\text { by frailty level in community } \\
\text { dwelling older adults. }\end{array}$ & $\begin{array}{l}120 \text { community } \\
\text { dwelling older adults } \\
\text { Age }>65 \\
\text { Without gait or } \\
\text { mobility disorders }\end{array}$ & $\begin{array}{l}\text { Monitoring daily physical } \\
\text { activity, specifically } \\
\text { quantification of postural } \\
\text { transitions using inertial } \\
\text { wearable sensors may } \\
\text { provide an objective tool } \\
\text { for assessing frailty during } \\
\text { unsupervised conditions } \\
\text { in home. }\end{array}$ \\
\hline $\begin{array}{l}\text { Peek et al. (2016), The } \\
\text { Netherlands }\end{array}$ & $\begin{array}{l}\text { Qualitative } \\
\text { explorative } \\
\text { field study }\end{array}$ & $\begin{array}{l}\text { To explore which factors influence } \\
\text { the level of use of various types } \\
\text { of technology by older adults who } \\
\text { are aging in place and to describe } \\
\text { these factors in a comprehensive } \\
\text { model }\end{array}$ & $\begin{array}{l}53 \text { community } \\
\text { dwelling older adults } \\
\text { Aged } 68-95\end{array}$ & $\begin{array}{l}\text { Older adults perceptions } \\
\text { and use of technology } \\
\text { are embedded in their } \\
\text { personal, social and } \\
\text { physical context. }\end{array}$ \\
\hline $\begin{array}{l}\text { Rahemi et al. (2018), } \\
\text { USA }\end{array}$ & $\begin{array}{l}\text { Observational } \\
\text { cohort study }\end{array}$ & $\begin{array}{l}\text { To investigate the feasibility of } \\
\text { developing a foot-worn sensor to } \\
\text { assess frailty }\end{array}$ & $\begin{array}{l}161 \text { community } \\
\text { dwelling older adults } \\
\text { Age }>55 \\
\text { Non-frail } 49 \\
\text { Pre-frail } 92 \\
\text { Frail } 20\end{array}$ & $\begin{array}{l}\text { Foot-worn sensor- } \\
\text { derived gait measures } \\
\text { during propulsive phase } \\
\text { of walking can be } \\
\text { sensitive metrics in frailty } \\
\text { assessment. }\end{array}$ \\
\hline $\begin{array}{l}\text { Razjouyan et al. } \\
\text { (2018), USA }\end{array}$ & $\begin{array}{l}\text { Cross-sectional } \\
\text { study }\end{array}$ & $\begin{array}{l}\text { To determine which sensor- } \\
\text { derived parameters are capable } \\
\text { of discriminating between the } 3 \\
\text { frailty categories. }\end{array}$ & $\begin{array}{l}153 \text { community } \\
\text { dwelling older adults } \\
\text { Age }>60 \\
\text { Able to walk } 15 \text { feet } \\
\text { independently with or } \\
\text { without aid }\end{array}$ & $\begin{array}{l}\text { A pendant sensor can } \\
\text { identify pre-frailty via } \\
\text { daily home monitoring. }\end{array}$ \\
\hline $\begin{array}{l}\text { Rye Hanton et al. } \\
\text { (2017), USA }\end{array}$ & $\begin{array}{l}\text { Observational } \\
\text { cohort study }\end{array}$ & $\begin{array}{l}\text { To demonstrate data derived } \\
\text { from ubiquitous mobile phone } \\
\text { technology can be employed to } \\
\text { continuously measure aspects of } \\
\text { participant health status, including } \\
\text { step counts, gait speed and activity } \\
\text { level. }\end{array}$ & $\begin{array}{l}43 \text { ambulatory, } \\
\text { community dwelling } \\
\text { older adults } \\
25 \text { robust } \\
18 \text { frail }\end{array}$ & $\begin{array}{l}\text { Continuous mobile } \\
\text { phone-based measures } \\
\text { of activity and mobility } \\
\text { can differentiate between } \\
\text { frailty and non-frail older } \\
\text { adults. }\end{array}$ \\
\hline $\begin{array}{l}\text { Schwenk et al. (2015), } \\
\text { USA }\end{array}$ & $\begin{array}{l}\text { Observational, } \\
\text { cross-sectional } \\
\text { study }\end{array}$ & $\begin{array}{l}\text { To examine the ability of wearable } \\
\text { sensor-based in-home assessment } \\
\text { of gait, balance, and physical } \\
\text { activity to discriminate between } \\
\text { frailty levels. }\end{array}$ & $\begin{array}{l}125 \text { older adults } \\
44 \text { non-frail } \\
60 \text { pre-frail } \\
21 \text { frail }\end{array}$ & $\begin{array}{l}\text { Unique parameters } \\
\text { derived from objective } \\
\text { assessment of gait, } \\
\text { balance, and physical } \\
\text { activity are sensitive for } \\
\text { the identification of pre- } \\
\text { frailty and classification } \\
\text { of a subjects' frailty level. }\end{array}$ \\
\hline
\end{tabular}




\begin{tabular}{|l|l|l|l|l|}
\hline $\begin{array}{l}\text { Toosizadeh et al. } \\
\text { (2015), USA }\end{array}$ & $\begin{array}{l}\text { Cross sectional } \\
\text { study }\end{array}$ & $\begin{array}{l}\text { To objectively identify frailty } \\
\text { using wireless sensors and } \\
\text { an upper extremity motion } \\
\text { assessment that does not rely on } \\
\text { gait. }\end{array}$ & $\begin{array}{l}117 \text { community } \\
\text { dwelling older adults } \\
50 \text { nonfrail }\end{array}$ & $\begin{array}{l}\text { This upper extremity } \\
\text { frailty assessment method } \\
\text { integrates low cost sensors } \\
\text { and implemented in less } \\
\text { than } 1 \text { minute objectively } \\
\text { identifies frailty. }\end{array}$ \\
\hline
\end{tabular}

\section{References}

Apostolo, J., Cooke, R., Bobrowicz-Campos, E., Santana, S., Marcucci, M., Cano, A., Vollenbroek-Hutten, M., Germini, F., D'Avanzo, B., Gwyther, H., \& Holland, C. (2018). Effectiveness of interventions to prevent pre-frailty and frailty progression in older adults: A systematic review. JBI Database of Systematic Reviews and Implementation Reports, 16(1). http://dx.doi.org/10.11124/JBISRIR-2017-003382

Buckinx, F., Rolland, Y., Reginster, J., Ricour, C., Petermans, J., \& Bruyere, O. (2015). Burden of frailty in the elderly population: Perspectives for a public health challenge. Archives of Public Health, 73(1). http://dx.doi.org/10.1186/s13690-015-0068-x

Chang, S. \& Lin,P. (2015). Frail phenotype and mortality prediction: A systematic review and meta-analysis of prospective cohort studies. International Journal of Nursing Studies, 52, 13621374. http://dx.doi.org/10.1016/j.ijnurstu.2015.04.005

Clegg, A., Young, J., Iliffe, S., Rikkert, M.O., \& Rockwood, K. (2013). Frailty in elderly people. Lancet, 381(9868), 752-762. http://dx.doi.org/10.1016/S0140-6736(12)62167-9

Collard, R.M., Boter, H., Schoevers, R., \& Voshaar, R.C. (2012). Prevalence of frailty in community dwelling older persons: A systematic review. JAGS, 60, 1487-1492. http://dx.doi. org/10.1111/j.1532-5415.2012.04054.x

Conroy, S. \& Elliot, A. (2016). The frailty syndrome. Medicine, 45(1), 15-18. http://dx.doi.org/10.1016/j.mpmed.2016.10.010

Dekker-van Weering, M., Jansen-Kosterink, S., Frazer, S., \& Vollenbroek-Hutten, M. (2017). User experience, actual use, and effectiveness of an information and communication technology-supported home exercise program for pre-frail older adults. Frontiers in Medicine, 4(208). http://dx.doi. org/10.3389/fmed.2017.00208

De Labra, C., Guimaraes-Pinheiro, C., Maseda, A., Lorenzo, T., \& Millan-Calenti, J.C. (2015). Effects of physical exercise interventions in frail older adults: A systematic review of randomized controlled trials. BMC Geriatrics, 15(154). http:// dx.doi.org/10.1186/s12877-015-0155-4

De Vries, N.M., van Ravensberg, C.D., Hobbelen, J.S.M., Olde Rikkert, M.G.M., Staal, J.B., \& Nijhuis-van der Sanden, M.W.G. (2012). Effects of physical exercise therapy on mobility, physical functioning, physical activity and quality of life in community-dwelling older adults with impaired mobility, physical disability, and/or multi-morbidity: A metaanalysis. Aging Research Reviews, 11, 136-149. http://dx.doi. org/10.1016/j.arr.2011.11.002

Feng, Z., Lugtenberg, M., Franse, C., Fang, X., Hu, S., Jin, C., \& Raat, H. (2017). Risk factors and protective factors associated with incident or increase of frailty among community-dwelling older adults: A systematic review of longitudinal studies. PLoS One, 12(6). http://dx.doi.org/10.1371/journal.pone.0178383
Fried, L.P., Tangen, C.M., Walston, J., Newman, A.B., Hirsch, C., Gottdiener, J., Seeman, T., Russell, T., Kop, W.J., Burke, G., \& McBurnie, M.A. (2001). Frailty in older adults: Evidence for a phenotype. Journal of Gerontology, 56A(3), M146-M156. http://dx.doi.org/10.1093/gerona/56.3.m146

Galan-Mercant, A. \& Cuesta-Vargas, A.I. (2013). Differences in trunk accelerometry between frail and nonfrail elderly persons in sit-to-stand and stand-to-sit transitions based on a mobile inertial sensor. JMIR Mhealth Uhealth, I(2), e21. http://dx.doi. org/10.2196/mhealth.2710

Galan-Mercant, A. \& Cuesta-Vargas, A.I. (2014). Differences in trunk accelerometry between frail and non-frail elderly persons in functional tasks. BMC Research Notes, 7(100). http://dx.doi. org/10.1186/1756-0500-7-100

Galan-Mercant, A. \& Cuesta-Vargas, A.I. (2015). Clinical frailty syndrome assessment using inertial sensors embedded in smartphones. Physiologic Measurement, 36, 1929-1942. http:// dx.doi.org/10.1088/0967-3334369/1929

Geraedts, H.A.E., Zijlstra, W., Zhang, W., Spoorenberg, S.L.W., Baez, M., Khaghani, I., Baldus, H., \& Stevens, M. (2017). A home-based exercise program driven by tablet application and mobility monitoring for frail older adults: Feasibility and practical implications. Preventing Chronic Disease, 14(12). http://dx.doi.org/10.5888/pcd14.160227

Greene, B.R., Doheny, E.P., Kenny, R.A., \& Caulfield, B. (2014a). Classification of frailty and falls history using a combination of sensor-based mobility assessments. Physiological Measurement, 35, 2053-2066. http://dx.doi.org/10.1088/0967$3334 / 35 / 10 / 2053$

Greene, B.R., Doheny, E.P., O'Halloran, A., \& Kenny, R.A. (2014b). Frailty status can be accurately assessed using inertial sensors and the TUG test. Age and Ageing, 43, 406-411. http:// dx.doi.org/10.1093/ageing/aft176

Inouye, S.K., Studenski, S., Tinetti, M.E., \& Kuchel, G.A. (2007). Geriatric syndromes: Clinical, research and policy implications of a core geriatric concept. JAGS, 55(5), 780-791. http://dx.doi. org/10.1111/j.1532-5415.2007.01156.x

Kane, R.L., Shamliyan, T., Talley, K., \& Pacala, J. (2012). The association between geriatric syndromes and survival. JAGS, 60(3), 896-904. http://dx.doi.org/10.1111/j.15325415.2012.03942.x

Kojima, G. (2017). Frailty as a predictor of disabilities among community-dwelling older people: A systematic review and meta-analysis. Disability and Rehabilitation, 39(19). http:// dx.doi.org/10.1080/09638288.2016.1212282

Kojima, G. (2018). Frailty defined by FRAIL scale as a predictor of mortality: A systematic review and meta-analysis. JAMDA, 19, 480-483. http://dx.doi.org/10.1016/j.jamda.2018.04.006 
Martinez-Ramirez, A., Martinikorena, I., Gomez, M., Lecumberri, P., Millor, N., Rodriguez-Manas, L., Garcia, F.J., \& Izquierdo, M. (2015). Frailty assessment based on trunk kinematic parameters during walking. Journal of Neuroengineering and Rehabilitation. http://dx.doi.org/10.1186/s12984-015-0040-6

Mohler, J.M., Wendel, C.S., Taylor-Piliae, R.E., Toosizadeh, N., \& Najafi, B. (2016). Motor performance and physical activity as predictors of prospective falls in communitydwelling older adults by frailty level: Application of wearable technology. Gerontology, 62, 654-664. http://dx.doi. org/10.1159/000445889

Muchna, A., Najafi, B., Wendel, C.S., Schwenk, M., Armstrong, D.G., \& Mohler, J. (2018). Foot problems in older adults. Journal of the American Podiatric Medical Association, 108(2). http://dx.doi.org/10.7547/15-186

Ozaki, K., Kondo, I., Hirano, S., Kagaya, H., Saitoh, E., Osawa, A., \& Fujinori, Y. (2017). Training with a balance exercise assist robot is more effective than conventional training for frail older adults. Geriatrics and Gerontology International, 17, 1982-1990. http://dx.doi.org/10.1111/ggi.13009

Parvaneh, S., Mohler, J., Toosizadeh, N., Grewal, G.S., \& Najafi, B. (2017). Postural transitions during activities of daily living could identify frailty status: Application of wearable technology to identify frailty during unsupervised condition. Gerontology, 63, 479-487. http://dx.doi.org/10.1159/000460292

Peek, S.T., Luijkx, K.G., Rijnaard, M.D., Nieboer, M.E., van der Voort, C.S., Aarts, S., van Hoof, J., Vrijhoef, H.J.M., \& Wouters, E.J.M. (2016). Older adults' reasons for using technology while aging in place. Gerontology, 62, 226-237. http://dx.doi.org/10.1159/000430949

Pilotto, A., Boi, R., \& Petermans, J. (2018). Technology in geriatrics. Age and Ageing, 0, 1-4. http://dx.doi.org/10.1093/ ageing/afy026

Provencher, V., Beland, F., Demers, L., Desrosiers, J., Bier, N., Avila-Funes, J.A., Galand, C., Julien, D., Fletcher, J.D., Trottier, L., \& Hami, B. (2017). Are frailty components associated with disability in specific activities of daily living in community-dwelling older adults? A multicenter Canadian study. Archives of Gerontology and Geriatrics, 73, 187-194. http://dx.doi.org/10.1016/j.archger.2017.07.027

Puts, M.T.E., Toubasi, S., Andrew, M.K., Ashe, M.C., Ploeg, J., Atkinson, E., Ayala, A.P., Roy, A., Monforte, M.R., Bergman, H., \& McGilton, K. (2017). Interventions to prevent or reduce the level of frailty in community-dwelling older adults: a scoping review of the literature and international policies. Age and Ageing, 46, 383-392. http://dx.doi.org/10.1093/ageing/afw247

Rahemi, H., Nguyen, H., Lee, H., \& Najafi, B. (2018). Toward smart footwear to track frailty phenotypes using propulsion performance to determine frailty. Sensors, 18(1763). http:// dx.doi.org/10.3390/s18061763

Razjouyan, J., Naik, A.D., Horstman, M.J., Kunik, M.E., Amirmazaheri, M., Zhou, H., Sharafkhaneh, A., \& Najafi, B. (2018). Wearable sensors and the assessment of frailty among vulnerable older adults: An observational cohort study. Sensors, 18(1336). http://dx.doi.org/10.3390/s18051336

Robertson, D.A., Savva, G.M., \& Kenny, R.A. (2013). Frailty and cognitive impairment - a review of the evidence and causal mechanisms. Ageing Research Reviews, 12, 840-851. http:// dx.doi.org/10.1016/j.arr.2013.06.004

Rockwood, K. \& Mitnitski, A. (2011). Frailty defined by deficit accumulation and geriatric medicine defined by frailty. Clinical Geriatric Medicine, 27, 17-26. http://dx.doi.org/10.1016/j. cger.2010.08.008

Rye-Hanton, C., Kwon, Y., Aung, T., Whittington, J., High, R.R., Goulding, E.H., Schenk, A.K., \& Bonasera, S.J. (2017). Mobile phone-based measures of activity, step count, and gait speed: Results from a study of ambulatory adults in a naturalistic setting. JMIR Mhealth Uhealth, 5(10), e104. http://dx.doi. org/10.2196/mhealth.5090

Schwenk, M., Mohler, J., Wendel, C., D'Huyvetter, K., Fain, M., Taylor-Piliae, R., \& Najafi, B. (2015). Wearable sensor-based in-home assessment of gait, balance and physical activity for discrimination of frailty status: Baseline results of the Arizona Frailty Cohort Study. Gerontology, 61, 258-267. http://dx.doi. org/10.1159/000369095

Silva, R., Pizato, N., Da Mata, F., Figueiredo, A., Ito, M., \& Pereira, M.G. (2018). Mediterranean diet and musculoskeletal functional outcomes in community-dwelling older people: A systematic review and meta-analysis. Journal of Nutrition Health and Aging, 22(6), 655-663. http://dx.doi.org/10.1017/ s12603-017-0993-1

Siriwardhana, D.D., Hardoon, S., Rait, G., Weerasinghe, M.C., \& Walters, K.R. (2018). Prevalence of frailty and prefrailty among community-dwelling older adults in low-income and middle-income countries: A systematic review and metaanalysis. BMJ Open, 8, e018195. http://dx.doi.org/10.1136/ bmjopen-2017-018195

Theou, O., Stathokostas, L., Roland, K.P., Jakobi, J.M., Patterson, C., Vandervoort, A.A., \& Jones, G.R. (2011). The effectiveness of exercise interventions for the management of frailty: A systematic review. Journal of Aging Research. http://dx.doi. org/10.4061/2011/569194

Toosizadeh, N., Mohler, J., \& Najafi, B. (2015). Assessing upper extremity motion: An innovative method to identify frailty. JAGS, 63, 1181-1186. http://dx.doi.org/10.1111/jgs.13451

Tricco, A.C., Lillie, E., Zarin, W., O’Brien, K.K., Colquhoun, H., Levac, D., Moher, D., Peters, M.D.J., Horsley, T., Weeks, L., Hempel, S., Akl, E.A., Chang, C., McGowan, J., Stewart, L., Hartling, L., Aldcroft, A., Wilson, M.G., Garritty, C., ... Straus, S.E. (2018). PRISMA extension for scoping reviews (PRISMA-ScR): Checklist and explanation. Annals of Internal medicine, 169, 467-473. http://dx.doi.org/10.7326/M18-0850

Xue, Q. (2011). The frailty syndrome: Definition and natural history. Clinical Geriatric Medicine 27, 1-15. http://dx.doi. org/10.1016/j.cger.2010.08.009 